\title{
Analysis of Factors Influencing the Strategic Choice of Brand Architecture
}

\author{
Cancan Lu \\ Management School, Shanghai University of International Business and Economics, Shanghai, China \\ Email: cancan_525@163.com
}

Received April 2014

\begin{abstract}
At the description of corporate brand and product brand, this paper introduces two kinds of strategic choice of brand architecture which are giving priority to corporate brand and product brand. We called them corporate brand model and independent brand model. This paper also studies how the external environment, consumer and enterprises influence the choice.
\end{abstract}

\section{Keywords}

\section{Corporate Brand, Product Brand, Brand Architecture, Choose}

\section{Introduction}

With the growing competition in market, enterprises expand their scales through merger, acquisition and brand extension constantly. According to the statistics from Dealoaic, a company of investment consulting, in 2013 the global amount of mergers and acquisition has grown $5 \%$ to 2.81 trillion dollars. At the same time, in order to occupy more market segments, enterprises continue to carry out brand extension and new brand. Therefore, enterprises need to manage the numerous brands efficiently. For example, the world's two largest domestic consumer companies P \& G and Unilever, have more than 300 brands and 400 brands respectively. American Virgin Company touches record, aviation, telecommunications, wedding, hypermarkets, cola, financial and other industries. Volkswagen has more than a dozen brands, as Audi, Lamborghini, Porsche, Skoda, Bentley etc. At present, one of the most important aspects faced by the enterprises is how to manage so many brands effectively. Brand management involves many aspects, and the most important aspect is to choose what kind of brand architecture because it's not only a purely theoretical concept, but also an important management concept. If corporate cannot confirm their own brand architecture, it will lead to misallocation of resources and chaos of marketing strategy. Therefore, establish an effective brand architecture is essential for a corporate's development. Before discussing the strategic brand architecture in, this paper first discusses the following two concepts.

\subsection{Corporate Brand}

The academic explanation of the corporate brand has successively appeared corporate identity, corporate image and corporate association etc. Aaker thinks the corporate brand as the final brand aggregate, because the corporate represent an organization. Therefore the corporate brand plays the role of guarantor and driver, visible [1]. 
Clearly, he defined the corporate brand from brand portfolio perspective. In order to explain the corporate brand, Keller (2009) points out the conception of the corporate image in the third edition of "Strategic Brand Management". He thinks the corporate image refers to the associations about manufactured products and services as a whole in consumer's brain. When the corporate brand occupies the important position in the enterprise brand strategy, the corporate image is a very important associated factor [2]. At the same time, Keller strengthens the concept of corporate brand, he defines the corporate brand as differential responses of consumers, customers, employees, other companies and any other related supporters due to the speech, actions, products and services about brand assets [3]. Visibly, the definition of corporate brands is not the same because different scholars study it from different research angles. From the consumer's perspective, this paper defines the corporate brand as a corporate image and corporate associations, it describes the consumers' attitudes, emotions and cognitions about an corporate.

\subsection{Product Brand}

Product Brand is easily to understand. It is a brand of one specific product. Product brand includes two levels of meaning: one is the combination of the product name, terminology, mark, symbol, design; the other is the value-added of the series of relevant products. It contains two aspects of function and psychological benefits, such as product which can be on behalf of utility, the function, form, taste, price, convenience, service etc.

Corporate brand and product brand are two different concepts. Aaker points out that corporate and product (service) are two different carriers, the corporate brand emphasizes organization and attribute and product brand stressed the importance of products and services, there is a big difference between the them. Keller (2009) believes the corporate brand and product brand is different, because the former has a more broad brand associations, such as the brand is more easily excited and starts the consumer association, which has a very important effect on brand equity and the single brand market performance [4] The product brand is focused mainly on the nature, quality and benefits of the products.

\section{Brand Architecture}

The architecture of the so-called brand refers to the choice of brand subordinate and the relationships of all products [5]. It specifically regulates function and position of each brand in brand strategy. On the strategic level, brand architecture has two kinds of big directional selection. The first one model is giving priority to corporate brand, which we called corporate brand model, that is corporate brand is consistent with all products brand, or more focusing on corporate brand. For example, virgin use the corporate brand on all products in all areas of its business, and as the Buick Company owns Buick Lacrosse, Buick Excelle, Buick Hideo Models; Another one is the independent brand model, namely the corporate's products (services) use different individual brand. For example P\&G has Rejoice, Head and Shoulders, Crest, Chi Mei er, Tide, Pringles etc.

Different corporates choose the different architecture according to their own conditions. It seems that every corporation has a good management of brand architecture and has achieved great success. However, there are also so many corporations which have failure brand because of the lack of scientific and rational management of brand architecture. The study of brand architecture selection before mainly focused on the corporate factor, that is the relationship of product brands and the relationship between corporate brand and product brand only. But, it cannot be denied that the success of a certain brand is determined by consumers, and this paper is based on the brand concept from consumer's point of view. Therefore, it is necessary to take consumers factor into consideration on the process of brand architecture selecting. At the same time, culture, as an important variable, has a significant explanatory power on analyzing cross-regional business practice. So, we also take into account the culture factor. Next, this paper will elaborate on the external environment, the consumer and the corporate which influence the strategy choice.

\section{Factors Affecting the Architecture of the Brand Strategy}

\subsection{External Environment}

\subsubsection{Social Culture}

There are many research shows that the people of Europe and the Americas are with more personality, they advocate more personal independence, therefore, the European and American countries tend to choose independent 
brand model so that consumers can rely on a variety of innovative products to show their own personality.

On the contrary, Oriental countries, such as China, South Korea and Japan etc, are more emphasis on collectivism, unity and coordination. The crystallization of this culture has penetrated into every stage of enterprise management. All of the management, the marketing work must be unified in a collective culture so that the corporate choose the corporate brand model [6].

In addition, the oriental culture is more exquisite "origin", such as ancestry. This kind of culture has been influencing the Oriental consumers for long time. For the same product, consumers have different acceptance and purchase decision considering it is from a well-known large companies or born in a small corporate. The different phenomenon for this because consumers think big corporate has more capacity to produce this kind of product. Corporate's ability can cause consumers' association about product attribute. Capacity here refers to the professional level of production and providing products or services, such as technology innovation ability, production capacity [7].

\subsubsection{Market Factor}

The market factors that affecting brand architecture is the degree of homogeneity. The higher degree of homogeneity of the market, the more priority to corporate brand model. If degree of homogeneity is lower, corporate are more inclined to independent brand model. For example, the degree of homogeneity of PC market is relatively high, the enterprise is very difficult to find a new market segment, if the company uses the independent brand model that is bound to increase enterprise cost of new brand building and marketing. On the contrary, if the degree of homogeneity of the market is low, then the enterprise can create a new brand to occupy new market quickly, meanwhile building barriers to entry and creating profits.

\subsubsection{Technology}

If the technology updates faster, it's better to choose the corporate brand model. The creation of new brands, marketing, consumer accepting and earning profit return are not instantaneous, the whole process is a certain length of time. As frequent changes in technology markets, if companies choose the independent brand model, perhaps the product has been updated when its new brand has not been accepted by consumers. The product has been eliminated by the market but does not create value.

On the contrary, it can avoid the adverse impact on the brand when technology updating if the corporate chooses the corporate brand model. For example, in PC industry, each introduced new products take the brand architecture of adopting the "Corporate brand + Version" so that enterprises only need to publicize the function, attribute of the new product. This can not only reduce the cost of marketing, but also meet different needs of different people.

On the other hand, with the rapid development of Internet, the brand architecture selecting has changed dramatically. According to a new research report, by the end of 2014, the global Internet users will be close to 3 billion, this figure is equivalent to $40 \%$ of the world's population and two-thirds of the users will come from developing countries [8]. The scale of Chinese Internet users has reach to 0.6 billion ended December 31, 2013 and the Internet penetration rate is $45.8 \%$ [9]. In recent days, consumers have more opportunities to get the information of products and corporates. Now, consumers can easily gain related information of a certain brand through Internet when they face a new unfamiliar brand, for example, how the quality of the brand; which corporate the brand belongs to; the brand ranking, and so on. This will greatly reduce the information asymmetry than before and consumers are increasingly able to get enough information he needed at lower cost. Therefore, the corporate is more and more suitable for choosing the corporate brand model. Because even to choose the independent brand model, the perception of the products will be mainly from the corporate brand after the consumers search the ownership of the brand on the Internet. The consumers will firstly judge the corporate brand, then go for the evaluation of the product brand. There will be a big waste of the funds when building an independent brand. It is getting harder to establish unique brand image through independent brand model. At present, more and more corporates begin to focus on the building of corporate brand image can illustrate this opinion in a certain extent.

\subsection{Consumer}

Consumer maturity refers to the degree of price sensitivity and purchase experience of consumer [10]. The im- 
mature consumers will pay more attention to product's function and price. In this situation, it's better to adopt the corporate brand model because good corporate brand becomes the guarantee of quality and service commitment. For example, Chinese consumers tend to attach more importance to product specific attributes and price while ignoring the shopping process cost, time cost, spirit cost, service value and other factors compared to European consumers. Therefore, corporate brand model is a better choice in China. If consumers attach great importance to functional properties of products in purchase progress, it's better to choose the corporate brand model because it can make consumers be aware of what he buys is not only the product itself, but also the entire corporate and manufacturer. This model could strengthen the image that product is from a big company, not a small and let consumers feel better quality and more secure. In china, consumers always believe that big corporate has more resources and greater abilities to provide good products and services. Obviously, it is also consistent with the culture factor mentioned above.

\subsection{Corporate}

\subsubsection{Corporate Strategy}

The brand architecture strategy is one of the corporate's overall strategy, so it should reflect the goal structure and the choice of corporate's overall strategy [11]. It means that the strategic brand architecture is determined in a period of time once the overall goal of the corporate is for certain. According to the competition strategy theory of Potter, enterprises can choose between the low-cost strategy and the differentiation strategy, if the enterprises choose the former, it's better to choose a corporate brand model. Under this kind of architecture, corporate only needs to make corresponding marketing activities for one brand. It will play a propaganda effect on all products, and of course that can greatly reduce the cost for the corporate. If choosing the differentiation strategy, so it should tend to the independent product brand because one brand is difficult to meet the different needs of different consumers and more brands can adapt to different consumer groups.

\subsubsection{Brand Image}

The more consistent of corporate brand association and product brand is, the more the corporate should adopt corporate brand model because this model can make the product sharing corporate brand association, it also can expand the corporate brand association. For example, the Estee Lauder reminds people of high-end cosmetics, if the company launched another high-end products, it can continue to use the corporate brand.

On the contrary, if the company launched another low-grade product, it's better to avoid the use of the corporate brand because it would be detrimental to the corporate brand image. When the images of corporate brand and product brand are widely inconsistent, the best choice is adopt the independent brand model so as to avoid conflict of the two images.

\subsubsection{Correlation between each Product within the Enterprise}

If the correlation between each product within the enterprise is relatively strong, the enterprise should choose the corporate brand model. If the correlation is weak, it should adopt the independent brand model. Just imagine that if a chocolate company produce toilet cleaning agent and it adopt the corporate brand model, then this will make consumers don't know what course to take. In this case, it should take the independent brand model to weaken the influence of the corporate brand and avoid the negative impact on the company due to different nature of the products with the same brand.

\subsubsection{The Strength of Corporate Brand Driven Role}

In Aaker's book "Create a Strong Brand", he pointed out that brand has a driving role which is the decisive actor of customers to buy products. If the driving role of a corporate brand is strong, it should tend to the corporate brand as the leading because the strong corporate brand can help to expand product boundary and all products or services can share the corporate brand marketing efforts. For example, the virgin company established a very strong brand image, namely "challenges freedom and happiness" and the driven role of this image is very strong, so that the company can reach not related areas, such as airline, hotel, catering and other fields. On the contrary, if the corporate brand driven role is weak, it might as well choose the independent brand model because the weak corporate brand did not have driven effect on products.

The choice of brand architecture is not an arbitrary decision, we need to consider the external factors, con- 
sumer factors and corporate factors mentioned in this paper. It is also noted that different weights are also assigned to the three factors depending on the condition of a corporate. Some corporates firstly consider the consumer factors, some may consider corporate itself. In the following research, I hope to explore the path of brand architecture choice in depth.

\section{References}

[1] Aaker, D.A. (2013) Building Strong Brands. China Machine Press, Beijing.

[2] Kevin Lane, K. (2009) Strategic Brand Management. 3rd Edition, China Renmin University Press, Beijing.

[3] Chen, W.L. (2008) The Meaning, Characteristics and Significance of Corporate Brand. Science and technology innovation, 1, 54-56.

[4] Dai, C. (2010) Single Brand Structure: The Choice of Enterprise Brand Structure under the Oriental Culture. Southeast Communication, 10, 9-11.

[5] Huang, S.B. and Lu, T.H. (2000) Strategic Brand Architecture Choice: The Corporate Brand and Independent Brand. Marketing Management, 107, 22-24.

[6] Wu, S.L., Lu, T.H. and Jiang, L.X. (2009) Review on the Research of Corporate Brand. Foreign Economic and Management, 31, 30-37.

[7] Xiong, K. (2004) The Strategy and Tactic Selection of Brand Architecture. The Commercial Era, 18, 18-19.

[8] Xing, H.J. and Wang, B. (2012) The Analysis of Product Brand and Corporate Brand. Research of Economic Management, 6, 119-120.

[9] Wang, D. (2007) The Principle and Application of Brand Architecture. Business Research, 499, 45. 